\title{
Constitutional Identity as a tool to improve Defence Rights in European Criminal Law
}

Introduction

1. Fundamental rights protections in the AFSJ

2. Improving Fundamental Rights Standards through Constitutional Identity Exceptions

2.1 The Constitutional Identity Exception Explained Through Omega

2.2 The Constitutional identity Exception as Interpreted by the CJEU

3. Solange and National Differentiation within the AFSJ

4. The Taricco Saga as a New Beginning

4.1 Taricco I: Another Attempt to Foster Efficiency and Homogeneity? 18

4.2 The Controlimiti Doctrine as a Viable Alternative 21

4.3 Taricco II: The CJEU listening 23

Conclusions

26

\section{Abstract}

Since the early years of the European arrest warrant (EAW), fundamental rights concerns have been at the centre of the development of an extensive judicial cooperation in criminal matters that has taken place in the EU. The attempts to ensure compliance with minimum standards across the EU after Lisbon did not solve the other pressing issue in this area, namely the existence of different fundamental rights safeguards at national level. Melloni tried to settle this dispute by limiting the protection of fundamental rights to those harmonised by EU law, but recent case-law has questioned this approach. This article explores the possibility of applying article 4(2) TEU to protect a degree of legal diversity that contributes to improving the fundamental rights framework applicable to judicial cooperation measures. The goal is to analyse the possibility of implementing a limited constitutional identity exception that enables Member States to protect rights that are part of their constitutional identity. For this purpose, the recent case-law of the CJEU in the Taricco saga will be examined, and compared with the way in which domestic courts have implemented national identity exceptions domestically. 
The protection of fundamental rights within the AFSJ has been a controversial issue since Member States started cooperating in Justice and Home Affairs (hereinafter "JHA"). A lot has been written about the push towards securitisation, the lack of adequate fundamental rights protections, and the non-compliance of some Member States with ECHR standards. ${ }^{1}$ With the goal of tackling some of these issues, the Lisbon treaty incorporated the Charter as a binding instrument ${ }^{2}$, and included the possibility of adopting minimum standards for the protection of defence rights. ${ }^{3}$

Despite these improvements, the post-Lisbon scenario has shown that the fundamental rights framework applicable to judicial cooperation in criminal matters is still far from perfect. One of the main problems was exposed in Melloni that showed the different levels of fundamental rights protections available across the EU. ${ }^{4}$ This case exposed the conflict that arises when EU fundamental rights fall below the constitutional protections offered by Member States. EU fundamental rights protections are based on minimum requirements that usually reflect the case-law of the ECHR, especially in relation with fair trial guarantees. Limiting the protection of fundamental rights to these minimum guarantees, and ordering the disapplication of higher constitutional protections nationally has provoked a judicial conflict between courts and a significant lowering of fundamental rights standards across the EU. More precisely, Melloni implies that Member States that comply with minimum standards and offer limited or no additional safeguards can define the fundamental rights applicable across the EU, while the rest are forced to disapply constitutional provisions that improve defence rights. ${ }^{5}$

In turn, this article will explore the possibility of applying article 4(2) TEU to improve the protection of defence rights in the field of judicial cooperation in criminal matters. The goal is to create a fundamental rights framework that goes beyond minimum standards, and

\footnotetext{
${ }^{1}$ On the shortcomings of cooperation in JHA in the early years: Susie Alegre and Marisa Leaf, 'Mutual Recognition in European Judicial Cooperation: A Step Too Far Too Soon? Case Study-the European Arrest Warrant' (2004) 10 European Law Journal 200; Elspeth Guild, Constitutional challenges to the European Arrest Warrant (Wolf Legal Publishers 2007).

${ }^{2}$ Article 6(1) TEU.

${ }^{3}$ Article 82(2)b TFEU

${ }^{4}$ Case C-399/11 Stefano Melloni v Ministerio Fiscal [2013] ECR 107 (Melloni).

${ }^{5}$ lbid.
} 
transcends the prioritisation of security goals that characterise the development of judicial cooperation in JHA. Overall, the article will assess whether certain fundamental rights standards available nationally can be preserved under article 4(2) TEU, and whether they can be used to improve the protection of defence rights within the AFSJ. For this purpose, this article will briefly analyse the existing fundamental rights problems in the field of judicial cooperation in criminal matters and the different responses given by the CJEU in Section 1. Section 2 will examine the potential of applying article 4(2) TEU to protect fundamental rights that are part of Member States' constitutional identity. Then, Sections 3 and 4 will explore the use of this constitutional identity safeguard by national courts, as well as the recent caselaw of the CJEU in this matter.

\section{Fundamental rights protections in the AFSJ}

The early years of judicial cooperation in criminal matters saw the European arrest warrant (hereinafter "EAW") as its protagonist and fundamental rights as the main concern. Mutual recognition in criminal matters acted as a principle that ensured the free circulation of judicial decisions in the AFSJ following the model of the internal market. This principle is based on mutual trust that is built upon the assumption that Member States share equivalent fundamental rights standards. ${ }^{6}$ But this period also showed that not all Member States comply with ECHR standards in relation with the rights of the accused, and the Framework Decision on the EAW (hereinafter "FD on the EAW") demonstrated that defence rights were not equally respected all across the EU. ${ }^{7}$ The quasi-automatic nature of mutual recognition,

\footnotetext{
${ }^{6}$ On the application of the principle of mutual recognition and fundamental rights in criminal justice see: Christine Janssens, 'The Principle of Mutual Recognition as Legislative Impetus for Efficient Judicial Cooperation in Criminal Matters', in The Principle of Mutual Recognition in EU law (Oxford Publishers 2013); Valsamis Mitsilegas, 'The Principle of Mutual Recognition as Legislative Impetus for Efficient Judicial Cooperation in Criminal Matters' (2015) 6 New Journal of European Criminal Law 457.

${ }^{7}$ The concerns about the protection of fundamental rights in the case of the EAW, especially with regard to the different standards in pre-trial detention and detention conditions was made obvious by reports such as: Justice, European Arrest Warrants: Ensuring an Effective Defence (2012 Justice Report); Anne Weyembergh, 'Critical Assessment of the Existing European Arrest Warrant Framework Decision' in European Added Value Assessment The EU Arrest Warrant (2014) European Parliamentary Research Service EAVA 6/2013.
} 
the lack of fundamental rights bars to execute EAWs, and the disparity in fundamental rights safeguards characterised the early years of the EAW. ${ }^{8}$

Although the preamble of the FD on the EAW acknowledges the importance of protecting fundamental rights, its breach is not included as a formal bar to extradition, and the presumption of mutual trust appeared to be almost unquestionable for the CJEU in the early years. A different issue is how national courts dealt with the issue. For instance, the UK Extradition Act 2003 contains a bar to extradition in Section 21 a(1) that requires that judges decide on whether the person's extradition would be compatible with his or her rights under the ECHR at the extradition hearing. This Act also includes a proportionality check added after the block opt-out and selective opt-in of the UK into the AFSJ with the Lisbon Treaty. Other jurisdictions, such as Italy, also include bars to extradition in cases of political offences that are not contained or authorised by the FD on the EAW. ${ }^{9}$

Despite the concerns of national courts over the protection of fundamental rights, it took the CJEU more than a decade to rule on the possibility of rejecting the execution of EAWs in cases of Member States that do not comply with ECHR or Charter standards. More precisely, it was in Căldăraru and Aranyosi that the CJEU showed that it was willing to take fundamental rights seriously. ${ }^{10}$ The joined cases responded to requests for preliminary rulings launched by the Hanseatisches Oberlandesgericht of Bremen (the Higher Regional Court of the Hanseatic Region). In both cases, the Court asked whether article 1(3) FD on the EAW should be interpreted as allowing the surrender of individuals in cases in which they might be at risk of being exposed to inhuman or degrading treatment. ${ }^{11}$ The accused were going to be surrendered to Hungary and Romania, and the German Court was worried about the overcrowding of prisons and, more generally, about prison conditions in countries that had been found in breach of ECHR standards. ${ }^{12}$ Particularly worrying was the case of Romania,

\footnotetext{
${ }^{8}$ Recital 12 of the Preamble of the FD on the EAW states that 'This Framework Decision respects fundamental rights', but it does not include the non-compliance with fundamental rights as a ground for non-execution.

${ }^{9}$ Statute No. 69 of 22 April 2005, which implements the FD into Italian law includes article 18(1)f that bans the surrender of individuals for political offences, excluding crimes of terrorism.

10 Joined Cases C-404/15 Pál Aranyosi and C-659/15 Robert Căldăraru [2016] ECLI:EU:C:2016:198.

${ }^{11}$ Case C-404/15 Pál Aranyosi, Request for a preliminary ruling from the Hanseatisches Oberlandesgericht in Bremen (Germany) lodged on 24 July 2015 [2016] ECLI:EU:C:2016:198.

12 See the pilot judgement of the ECHR in Varga and Others $v$ Hungary (2015) ECHR 422, which found a systemic violation of article 3 ECHR due to the overcrowding of Hungarian prisons (similar to the Torreggiani $v$ Italy case).
} 
where the Committee on the Prevention of Torture (CPT) had documented overcrowding amounting to a violation of article 3 of the ECHR (equivalent to article 4 of the Charter). ${ }^{13}$

Faced with this situation, the CJEU had to balance the application of a quasi-automatic principle of mutual recognition as the cornerstone of judicial cooperation with the absolute right not to suffer from inhuman or degrading treatment according to article 4 of the Charter (article $3 \mathrm{ECHR}$ ). The result was that the CJEU accepted the rebuttable nature of mutual trust in this area, ${ }^{14}$ and acknowledged the need to balance compliance with article 4 of the Charter with the need to build an AFSJ based on mutual trust. Accepting the rebuttable nature of mutual trust seemed a logical decision given that the assumptions that underpin this principle, namely the existence of equivalent fundamental rights protections, had been undermined.

In its ruling, the Court reaffirmed the centrality of mutual trust as the basis for mutual recognition that requires the existence of a presumption according to which EU member states comply with their fundamental rights obligations. ${ }^{15}$ But the innovative part is that it also accepted that such mutual trust can be rebutted under certain circumstances. ${ }^{16}$ As a consequence, the Court imposes a two stage test in cases in which a judicial authority of a Member State believes that there is a risk that the rights of the accused will be violated. In a first stage, the Court must establish if the prison conditions in the requesting state are such as to put at risk the rights guaranteed by article 4 of the Charter.${ }^{17}$ In a second stage, the Court has to analyse if there are substantial grounds to believe that the requested individual will be subjected to inhuman or degrading treatment in the requesting state. After this analysis, if the judicial authority believes that there is a real risk that the person will be the subject to a treatment that could amount to an article 4 violation, it must defer the execution of the EAW until the issuing authorities provide enough evidence to discount such risk. If such information

\footnotetext{
${ }^{13}$ Committee for the Prevention of Torture of the Council of Europe, Rapport au Gouvernement de la Roumanie relatif à la visite effectuée en Roumanie par le Comité européen pour la prévention de la torture et des peines ou traitements inhumains ou dégradants du 5 au 17 juin 2014 (2015), 31.

${ }^{14}$ This had previously happened in another area of the AFSJ, namely with asylum laws. For more information on this issue see: Evelien Brouwer, 'Mutual Trust and the Dublin Regulation: Protection of Fundamental Rights in the EU and the Burden of Proof' 9 Utrecht Law Review 135.

15 Joined cases Aranyosi and Căldăraru (n 10), paras 191-192.

${ }^{16} \mathrm{Ibid}$, para 82.

17 Ibid, para 88.
} 
is not provided by the issuing authorities within a reasonable time, the executing authority will have to deny the execution of the warrant. ${ }^{18}$

Căldăraru and Aranyosi represented a milestone for the protection of fundamental rights that is consistent with some of the legislative efforts made to improve the protection of defence rights within the AFSJ. ${ }^{19}$ It offers a consistent answer for Member States that are found in breach of ECHR and Charter rules, but it also leaves many questions unanswered. First of all, it is unclear whether the protection afforded to the right not to suffer inhuman or degrading treatment can be extended to other non-absolute rights insofar as the CJEU only refers to the protection of article 4 rights in the operating part of the judgment. ${ }^{20}$ In other words, despite significantly advancing the protection of fundamental rights by acknowledging the rebuttable nature of mutual trust, it is questionable whether this judgment is applicable to all the cases in which the fundamental rights of the accused are at risk.

Additionally, this ruling does not solve the issue that is at the heart of many current disputes between the CJEU and national constitutional courts. This issue concerns the disapplication of fundamental rights rules embedded in national constitutions that are meant to supplement the minimum standards of the ECHR and EU law domestically. The CJEU tried to settle this issue with Melloni, a case in which the Court ruled out the possibility of upholding higher fundamental rights standards in areas harmonised by EU law. ${ }^{21}$ Arguably, the reasoning of the Court implies that EU law (mainly the Charter, the Roadmap Directives, and the CJEU's caselaw) and ECHR norms set the parameters of defence rights applicable when executing an EAW. Conversely, higher national standards must be disapplied in to prioritise the efficiency of EU criminal law instruments.

An alternative solution is the protection of constitutional rights as part of Member States' identities following the mandate of article 4(2) TEU. This mechanism avoids a race to the bottom in the field of fundamental rights that is inevitable if the protection of the rights of

\footnotetext{
18 Ibid, para. 89.

19 The Resolution of the Council of 30 November 2009 on a Roadmap for strengthening procedural rights of suspected or accused persons in criminal proceedings [2009] OJ C 295/1 includes 8 directives that improve minimum rights in certain areas and have been adopted pursuant to article 82(2)b TFEU.

${ }^{20}$ On the unanswered questions in Căldăraru and Aranyosi: Szilárd Gáspár-Szilágyi, Joined Cases Aranyosi and Căldăraru: Converging Human Rights Standards, Mutual Trust and a New Ground for Postponing a European Arrest Warrant (2016) 24 European Journal of Crime, Criminal Law and Criminal Justice 194, 219.

${ }^{21}$ Melloni (n 4).
} 
the accused is limited to those protected by the Charter, the ECHR, and other directives. Member States provide additional safeguards applicable to criminal law proceedings that are usually embedded in national constitutions. Forcing them to disapply these provisions can trigger a judicial conflict between courts, and does not accomplish the goal of improving the protection of defence rights. Instead, article 4(2) TEU can be used to provide a limited protection of these rights that are at the heart of a Member State's constitutional identity.

\section{Improving Fundamental Rights Standards through Constitutional Identity Exceptions}

\subsection{The Constitutional Identity Exception Explained Through Omega}

The goal of this article is to explain how article 4(2) TEU can be used to preserve higher national fundamental rights standards. This approach is significantly different from the one proposed by Spanish Constitutional Court (hereinafter "the TC") in the case of Melloni, and rejected by the CJEU. On this occasion, the Court had to decide on the surrender of Mr Stefano Melloni to Italy to serve a sentence delivered in a trial held in absentia. The CJEU had to ponder the possibility of applying additional safeguards available at national level for trials in absentia, and it did so by examining the scope of application of article 53 ECHR.

The origin of the dispute lies in the obligation of executing an EAW issued by Italy against Mr Stefano Melloni as this case complied with the requirements set by article 4(1)a of the FD on the EAW for trials in absentia. However, article 24(2) of the Spanish Constitution and the interpretation of this provision that regulates the right to a fair trial barred extradition in cases adjudicated in absence, unless the person had the right to a full retrial. ${ }^{22}$ There was consolidated case-law of the TC that ruled that the right to participate in the trial and to defend oneself was part of the absolute content of the constitutional right to a fair trial. ${ }^{23}$ The different interpretation of the right to a fair trial under EU law and Spanish law exemplifies the judicial conflict between national constitutional courts and the CJEU that characterises judicial cooperation in criminal matters. In this case, minimum standards set by the Charter,

22 Judgment of the Spanish Constitutional Court 91/2000 of 30 March 2000 (Available at http://hj.tribunalconstitucional.es/pt/Resolucion/Show/4075) summarises the doctrine of the TC in this matter. ${ }^{23}$ This doctrine was established for extradition cases in Judgment of the Spanish Constitutional Court 91/2000 (n 22), and was extended to the EAW in Judgment of the Spanish Constitutional Court 177/2006 of 5 June 2006 (Available at http://hj.tribunalconstitucional.es/en/Resolucion/Show/5779). 
the FD on the EAW, the ECHR, and the Roadmap Directives for trials in absentia had been satisfied. But these safeguards acted as minimum standards, in other words, as the minimum common denominator that most national legal systems supplement with additional constitutional safeguards.

The main issues that the Court had to address was deciding whether these constitutional standards could act as a limit to mutual recognition, or whether the only standards applicable were the minimum rights set by the FD on the EAW. The TC tried to reconcile both legal systems with an interpretation of article 53 of the Charter that was in line with article 53 ECHR. ${ }^{24}$ In other words, the TC tried to reconcile article 4(1)a FD on the EAW with article 24(2) of the Spanish Constitution by interpreting Charter rights as a minimum floor of protection to which Member States could add national safeguards. But the CJEU dismissed this option, and ruled that article 53 of the Charter cannot be used by Member States to grant further rights in areas under harmonisation. ${ }^{25}$

Arguably, the Court was trying to avoid any possibility of using article 53 to limit integration within the AFSJ. With its reasoning, the CJEU prevented a very lax interpretation of article 53 that could be used to limit the automaticity of mutual recognition. It seems that the fear of the Court was that the functioning of judicial cooperation in criminal matters would be compromised if Member States were allowed to use national fundamental rights to limit the application of mutual recognition. Arguably, if the CJEU had allowed this extensive interpretation of article 53, the effectiveness of the principle of mutual recognition, mutual trust, and even the primacy of EU law would have been called into question as Member States would have been able to add any safeguards to the FD on the EAW.

Additionally, national constitutional courts that have voiced their concerns about integration within the AFSJ could use constitutional rights to limit integration in this controversial field. Instead of doing that, the CJEU ruled that Member States are not allowed to uphold higher standards in areas where the EU has harmonised fundamental rights. ${ }^{26}$ The Court's approach

\footnotetext{
${ }^{24}$ On the interpretation of articles 53 ECHR: Catherine Van de Heyning, 'No Place Like Home-Discretionary Space for the Domestic Protection of Fundamental Rights', in Piet Van Nuffel, Catherine van de Heyning, Patricia Popelier (eds), Human Rights Protection in the European Legal Order: The Interaction between the European and the National Courts (Cambridge, Intersentia, 2011) 65, 71-78.

${ }^{25}$ Melloni (n 21), paras 55-57.

${ }^{26}$ Ibid, paras 62-63.
} 
is backed by authors, such as De Witte, who argue that, 'It is wise for the Court not to adapt the "maximum standard" of protection but to exercise some judicial restraint in applying fundamental rights'. ${ }^{27}$

On the other hand, neither the CJEU nor the TC analysed the application of article 4(2) TEU to solve this conflict. This provision has a more limited scope than the interpretation of article 53 that the Court was suggesting as article 4(2) TEU would only be applicable to constitutional rights that are part of the constitutional identity of a Member State. ${ }^{28}$ In other words, Member States would not be able to limit the supremacy of EU law with every additional national safeguard. Instead, they would have an instrument applicable to cases in which the essential content of its constitutional identity is violated, which would be in line with the doctrines developed by national constitutional courts, such as the identity review of the German Federal Constitutional Court (hereinafter "BVerfGE") or the controlimiti test of the Italian Constitutional Court (hereinafter "Corte Cost"). This could be a reasonable compromise between the absolute primacy of EU law that can trigger a race to the bottom in fundamental rights if only minimum standards are applied, and the need to guarantee the free circulation of judicial decisions in a field based on mutual trust.

\subsection{The Constitutional identity Exception as Interpreted by the CJEU}

The interpretation of article 4(2) TEU should, in any case, be in line with Omega. ${ }^{29}$ In this case, the CJEU accepted a limitation to the free movement services to preserve the principle of human dignity as part of the constitutional identity of Germany. More precisely, the Court accepted the prohibition to commercialise laser gun games on the grounds that these games breached the right to human dignity under article 1 of the German Basic Law. ${ }^{30}$ It ruled that the prohibition put in place by the Bonn Police Department was a restriction to the freedom

\footnotetext{
${ }^{27}$ Bruno de Witte, 'The Past and Future of the European Court of Justice in the Protection of Fundamental Rights' in John Norton and Philip Alston (eds.), The EU and Human Rights (Oxford University Press 1999), 882.

${ }^{28}$ A summary of the different interpretations of article 4(2) can be found in Hermann-Josef Blanke and Stelio Mangiameli (eds.), The Treaty on European Union (TEU): A Commentary (Springer 2013), 186-201. In page 198, the authors note that the national identity of a Member States contains, 'a stock of ideas and values that determine the self-conception and understanding of each State or people'. But the authors also note that '[these identities] are relevant insofar as they are laid down in their constitutions or national procedures'.

${ }^{29}$ Case C-36/02, Omega Spielhallen- und Automatenaufstellungs-GmbH v Oberbürgermeisterin der Bundesstadt Bonn [2004] ECR I-09609 (Omega).

${ }^{30} \mathrm{Ibid}$, para 11.
} 
of movement of goods and services, but accepted it on the basis of the public policy exception. $^{31}$

In practice, the situation in Omega was very similar to the one explained in Melloni. Both cases concerned the application of mutual recognition, albeit in very different areas. In Omega, mutual recognition should have been applied to facilitate the free movement of goods following the CJEU's case-law in Cassis de Dijon. ${ }^{32}$ When applied in this area, mutual recognition implies that a Member State has to recognise and accept the commercialisation of the goods legally produced and commercialised in another Member State. ${ }^{33}$ The same principle applies to judicial and police cooperation in criminal matters, but in these cases mutual recognition is applied to the judicial decisions that have to be recognised and executed by the judicial authorities of other Member States. ${ }^{34}$

Taking into account that judicial cooperation is based on a principle borrowed from the internal market, it seems reasonable to assume that a certain degree of differentiation could also be applied to the AFSJ. Nevertheless, it is worth mentioning that the harmonisation of fundamental rights standards in the AFSJ is something that distinguishes this field from the internal market, where mutual recognition was a principle of judicial creation with few exceptions, such as the protection of public health and safety. Conversely, it could be argued that fundamental rights standards have been harmonised to a certain extent through the Charter and the Roadmap Directives on Defence Rights. Additionally, this case differs from others that have arisen in relation with the EAW because it involves national legislation that restricts a fundamental freedom of movement, rather than national laws that breach secondary legislation.

Nevertheless, the more intrusive nature of mutual recognition when applied to criminal law measures should justify a limited application of the constitutional identity exception that is in line with Omega. In fact, Aida Torres Perez argues that there is no reason why a restriction based on national constitutional laws applied to the effectiveness and primacy of EU law in

\footnotetext{
${ }^{31} \mathrm{lbid}$, paras 39 and 41

${ }^{32}$ Case 120/78 Rewe-Zentral AG v Bundesmonopolverwaltung für Branntwein [1978] ECR 649 (Cassis de Dijon).

${ }^{33}$ On the application of the principle of mutual recognition in the internal market: Christine Janssens, 'The Principle of Mutual Recognition as Legislative Impetus for Efficient Judicial Cooperation in Criminal Matters', in The Principle of Mutual Recognition in EU law (Oxford Publishers 2013), 11.

34 Ibid, paras 166-167.
} 
the field of free movement laws cannot be applied to the AFSJ according to article 4(2) TEU. ${ }^{35}$ This author goes a step further and even claims that more protective national standards could also be accommodated under article 53 of the Charter.

In any case, the CJEU lost the opportunity to analyse the potential of article 4(2) TEU and the Omega case-law in Melloni, a case that concerned one of the flagship measures of judicial cooperation in criminal matters. Instead, it ruled exclusively on the basis of the interpretation of article 53 following the question asked by the Spanish Court. Conversely, AG Bot referred to the possibility of applying the national identity exception, but concluded that the additional safeguards provided by the TC for trials in absentia were not part of the constitutional identity of Spain according to the allegations submitted by the Spanish government representatives. ${ }^{36}$ The Opinion of AG Bot was relevant because it acknowledged the applicability of this exception to the AFSJ, but failed to identify who were the legitimate interpreters of the Spanish Constitution. Under Spanish constitutional law, it is not the Spanish government or its representatives who interpret the Spanish Constitution, as this is a task exclusively entrusted to the TC. ${ }^{37}$ AG Bot also failed to engage with the case-law of the TC that included the safeguards of trials in absence as components of the essential content of the right to a fair trial. ${ }^{38}$

The CJEU did not engage with these arguments, and did not analyse article 4(2) TEU as the basis for its ruling. Although this was a lost opportunity that the CJEU could have used to incorporate article 4(2) TEU into the AFSJ and to improve the protection of fundamental rights, it is equally true that the TC failed to refer to this provision in its submissions. This fact is relevant if one examines the Omega case, where the CJEU seems to suggest that national courts should be the ones to analyse the constitutional rights at stake, their relevance, and their impact on the constitutional identity of the Member State. On the other hand, the CJEU's task should be limited to analysing the impact of these national provisions upon EU law. ${ }^{39}$ This

\footnotetext{
${ }^{35}$ Aida Torres Pérez, 'Melloni in Three Acts: From Dialogue to Monologue' (2014) 10 European Constitutional Law Review 308.

36 Ibid, para 138.

${ }^{37}$ According to article 1 of Statute No 2/1979 of 2 October of the Constitutional Court, the Spanish Constitutional Court is the supreme interpreter of the Constitution.

${ }^{38}$ See Judgment of the Spanish Constitutional Court 91/2000 (n 22) and Judgment of the Spanish Constitutional Court 177/2006 (n 23).

${ }^{39}$ Omega (n 29), para 39. In this ruling, the CJEU accepts the meaning and impact of the principle of human dignity upon the constitutional identity of Germany as elaborated by the referring Court, and it does not
} 
is in line with article 19 TEU that confers the mandate of interpreting EU law to the CJEU, while the interpretation of national constitutional law remains in the hands of national courts.

It is difficult to predict whether the CJEU would have accepted that the constitutional identity of Spain was endangered by the derogation of additional protections available for trials in absentia. At this point, the implementation of the Melloni judgment domestically without any critique from the TC could even be used to reject the proposition according to which the protections for trials in absentia are part of Spanish Constitutional identity. Nevertheless, if one considers the TC's case-law in this matter and the analysis of some Spanish authors, the status of the protections applicable to trials in absentia seems to be an unquestionable thing. ${ }^{40}$ In any case, the CJEU would still have had to analyse whether this interpretation of the Spanish constitutional identity was worthy of protection under EU law. But it seems that the CJEU's case-law and the pragmatic reasons according to which the CJEU would prioritise the efficiency and unity of EU law suggest that national courts have to raise article 4(2) TEU if they want the CJEU to consider this exception. ${ }^{41}$ The fact that the TC did not raise this clause in Melloni explains the difference between the one-sidedness of this case and the judicial dialogue established in Taricco. ${ }^{42}$

All in all, Melloni brought the problem of fundamental rights standards to the spotlight, and showed the importance of national constitutional rights in the field of judicial cooperation in criminal matters. When adjudicating this case, the CJEU rejected an interpretation of article 53 that would allow national courts to impose additional safeguards in relation with every fundamental right harmonised by EU law. This interpretation is nothing new insofar as it could put the functioning of the principle of mutual recognition in danger. ${ }^{43}$ This principle is based

\footnotetext{
challenge the impact that the sale of laser videogames would have on this principle. More importantly, the referring court was not the BVerfGE as the supreme interpreter of the German Basic Law but the Federal Administrative Court. Despite this fact, the CJEU accepted the interpretation of this regional court, and does not challenge it in any way.

${ }^{40}$ See Judgment of the Spanish Constitutional Court 91/2000 (n 22) and Judgment of the Spanish Constitutional Court 177/2006 (n 23), and Aida Torres Perez (n 35).

${ }^{41}$ Leonard Besselink, 'National and constitutional identity before and after Lisbon', (2010) 6 Utrecht Law Review $36,44$.

${ }^{42}$ See next Section for more information on the approach of the CJEU in the Taricco saga.

${ }^{43}$ Bruno de Witte (n 27); Elias Deutscher and Sabine Mair, 'National Constitutional Courts in the European Constitutional Democracy: A Reply to Jan Komárek' (2017) 15 International Journal of Constitutional Law 801.
} 
upon the existence of mutual trust between Member States, and would be inapplicable if Member States were allowed to set their own standards in relation with every right.

However, the Court did not rule on a more limited application of national fundamental rights under article 4(2) TEU. The TC did not mention this possibility in its submissions to the Court, and the CJEU decided to avoid a deep analysis of the issue. But examining Omega shows how a more limited application of the constitutional identity exception can be helpful to safeguard essential fundamental rights when EU protections are insufficient. The limited application of this exception would result in little disruption of the integration process, and would contribute to improving a fundamental rights framework that is currently limited to minimum standards. The following section explains how the BVerfGE's identity review can be used to identify the fundamental rights that are at the core of a Member State's constitutional identity, and are worthy of protection under article 4(2) TEU.

\section{Solange and National Differentiation within the AFSJ}

The way in which the BVerfGE has interpreted and applied its identity review is an example that could be used to guide the interpretation of article 4(2) TEU in the AFSJ. The BVerfGE has developed this identity review technique through the so-called Solange case-law, which has the goal of protecting fundamental rights and principles that are part of Germany's constitutional identity. Germany's constitutional identity includes all the elements that are unique to Germany, and acts as a limit to the application of EU or international laws that violate this singular identity. ${ }^{44}$

Some authors contend that this identity review has been used by the Court to signal the limits of European integration, as well as to reaffirm the supremacy of German Constitutional law. ${ }^{45}$ Following this logic, the identity review acts as a mechanism used by the BVerfGE to retain an 'ultimate authority' over the EU rules that are implemented in Germany. ${ }^{46}$ Its origins can be traced back to Solange I, a judgment based on the non-equivalence of fundamental rights

\footnotetext{
${ }^{44}$ On the importance of the identity review in Germany: Bill Davies, 'Resistance to European Law and Constitutional Identity in Germany: Herbert Kraus and Solange in its Intellectual Context' (2015) 21 European Law Review 434; Leonard F.M. Besselink, A Composite European Constitution (Europa Law Publishing 2007). ${ }^{45}$ Bill Davies (n 44).

${ }^{46}$ Karen Alter, Establishing the Supremacy of European Law: The Making of an International Rule of Law in Europe (Oxford University Press 2001) 94.
} 
protections within EC law. ${ }^{47}$ In this ruling, the BVerfGE established an identity review mechanism according to which EC legislation would not be applied in Germany insofar as it conflicted with core rights and principles guaranteed by the German Basic Law. This exception is the predecessor of the current identity review, but it is wider in scope than the current one, goes beyond what article 4(2) TEU permits, and it is based on the existence of a more limited catalogue of fundamental rights at the supranational level.

Solange II revisited this ruling, and modified the identity review mechanism bringing it closer to the current constitutional identity exception of article 4(2) TEU. ${ }^{48}$ This ruling acknowledged the improvements to the fundamental rights framework at European level, and reverted the initial presumption that required all EC acts to be checked to verify that they complied with German constitutional law. But the Court maintained a more limited identity review that can be assimilated to the constitutional identity clause of article 4(2) TEU. The BVerfGE noted that it would not exercise its review prerogatives, 'insofar as the European Communities ensure effective protection of fundamental rights that is substantially similar to the protection provided by the Basic Law, and insofar as it generally safeguards the essential content of these fundamental rights' ${ }^{49}$ In other words, a general presumption in favour of the equivalence between both systems would operate, with the identity review clause only being activated exceptionally when there is evidence that fundamental rights as guaranteed by the Basic Law might be at risk. The exceptionality of this mechanism, its applications only in relation with core constitutional rights, and the general presumption in favour of the applicability of EU law make the German identity review an example of how national courts and the CJEU could apply article 4(2) TEU into the AFSJ.

But the most recent ruling in this saga is Solange III, which is particularly important for this article as it was delivered in relation with the execution of an EAW. ${ }^{50}$ Similarly to Melloni, this case also concerned the execution of an EAW issued by Italy in relation with a trial held in absentia. But the BVerfGE decided to fundamentally challenge the CJEU's case-law by

\footnotetext{
${ }^{47}$ Internationale Handelsgesellschaft von Einfuhr- und Vorratsstelle für Getreide und Futtermittel [1974] Decision of 29 May 1974, BVerfGE 37, 271 CMLR 540 (Solange I).

${ }^{48}$ Order of the Second Senate of the German Constitutional Court of 22 October 1986 - 2 BvR 197/83 (Solange II).

49 Ibid, para 132.

${ }^{50}$ Order of the Second Senate of the German Constitutional Court of 15 December 2015 - 2 BVR 2735/14 (Solange III).
} 
recalling the centrality of constitutional rights as inalienable elements of Germany's constitutional identity, while disobeying the non-applicability of national fundamental rights in areas subject to harmonisation.

The Court had to rule on whether surrendering someone sentenced in absentia, who had not being informed in due course of the proceedings, and did not have the right to a retrial in Italy violated the principle of individual guilt in connection with the right to human dignity of article 1 of the Basic law. ${ }^{51}$ The BVerfGE ruled that the principle of individual guilt is intrinsically linked to the right to a fair trial that requires, 'minimum guarantees of the rights of the accused in criminal trials' ${ }^{52}$ The lack of a new evidentiary hearing violated these minimum guarantees, and thus violated the right to a fair trial as a constitutive element of the right to human dignity, which is an essential part of the constitutional identity of Germany. ${ }^{53}$ It followed that the BVerfGE had to reject the execution of the warrant.

Nevertheless, it is worth mentioning that the BVerfGE did not rely on this identity review to refuse the execution of this EAW. Instead, after carrying out its usual identity review, the Court concluded that it could reach a similar conclusion applying EU law because the EAW in question did not comply with the requirements for trials in absentia under article 4(a) FD on the EAW. It follows that this EAW breached the minimum guarantees provided by EU law as well as the principle of human dignity in German constitutional law. ${ }^{54}$ This made disapplying EU law unnecessary insofar as the same solution could be reached applying the FD on the EAW. In other words, the BVerfGE did not detonate the 'identity review bomb' that would have led to disapplying EU law unilaterally, and simply hinted that this was a possibility even in an area under harmonisation. ${ }^{55}$

In fact, there are some doubts as to whether the identity review was only introduced obiter dicta as a reaction to Melloni rather than with a real intention of claiming a national identity exception. ${ }^{56}$ According to this view, the German Court was only trying to signal to the CJEU

\footnotetext{
51 Ibid, para 13.

52 lbid, para 52.

${ }^{53}$ Georgios Anagnostaras, 'Solange III? Fundamental rights protection under the national identity review' (2017) 42 European Law Review 234.

54 Ibid, paras 84-90.

55 'Human Dignity, Identity Review of the European Arrest Warrant and the Court of Justice as a Listener in the Dialogue of Courts: Solange-III and Aranyosi' (2016) 12 European Constitutional Law Review 549, 553.

56 Ibid.
} 
that any attempt to impose EU law over national constitutional laws would result in the disapplication of EU law domestically. Even if this was the case, the identity review in Solange II and III still provides a good model upon which the interpretation of article 4(2) TEU could be based.

This ruling could be seen as a reaction against Melloni that does not have any long-term repercussions. However, another ruling of 2016 reaffirms the BVerfGE's position in Solange III by engaging in another identity review in yet another EAW case. ${ }^{57}$ On this occasion, the BVerfGE had to decide whether the execution of an EAW issued by the UK would breach the right of the accused to remain silent in connection with the right not to incriminate oneself. The issue at stake was whether Section 35 of the UK Criminal Justice and Public Order Act 1994, which allows the jury to draw inferences from the silence of the accused, violated the right to remain silent as part of the right to human dignity under German constitutional law. Contrary to UK law, in Germany, the right to remain silent is considered absolute, and does not allow for inferences to be drawn from it. ${ }^{58}$

Despite the differences between systems, the BVerfGE considered that the inferences that could be drawn from the silence of the accused under UK law were not serious enough to amount to a breach of article 1. But in any case, the Court considered that the risk that it posed to article 1 of the Basic law was great enough to engage in an identity review. In doing so, it highlighted the importance of this exception in an area where, according to the Melloni case-law, fundamental rights have to be drawn from EU sources. The other significant point is that the BVerfGE clarified the content of the principle of human dignity as an inalienable right under German Constitutional law. For this purpose, the Court avoided a vague conception of human dignity that could be used to limit integration in any field, and claimed that not every manifestation of this principle is equally protected. ${ }^{59}$ According to this ruling, the constitutional identity exception will only be applicable in cases in which the essence of the principle of human dignity is at risk.

\footnotetext{
${ }^{57}$ Order of the Second Senate of German Constitutional Court of 06 September 2016 - 2 BvR 890/16 (2 BvR 890/16).

${ }^{58}$ Section 136(1) of the Strafprozessordnung (German Criminal Procedural Code) notes that the accused may choose to remain silent at any point, and no consequences may arise from this decision.

${ }^{59} 2$ BvR 890/16 (n 57), para 36.
} 
Overall, the Solange saga, especially in Solange II and III, shows how the constitutional identity clause is already being applied by a National Constitutional Court without causing much disruption. The BVerfGE's case-law demonstrates the limited scope of this exception that only results in the disapplication of EU law when core constitutional rights are at risk. This interpretation of the constitutional identity exception in Germany does not contradict Omega, and could be used by the CJEU when applying article 4(2) TEU into judicial cooperation measures. At the same time, this identity review has been used by the BVerfGE to challenge the absolute primacy of EU law imposed by the CJEU in Melloni, and has provided an effective mechanism to protect fundamental rights domestically.

At the same time, it can also be argued that the BVerfGE has used this instrument with different purposes, such as limiting integration in certain areas with the Lisbon judgment, and has never been willing to follow through and trigger the disapplication of EU law. Indeed, the BVerfGE has historically used this mechanism to bark without biting. In other words, the Court has shown some contempt when faced with the possibility of disapplying EU law, a decision that could cause a conflict between courts without precedent.

Whatever the reason behind the BVerfGE's cautious approach to the national identity exception, the CJEU should not use it as an excuse to ignore it. Instead, it should take it into account when considering how to adequately safeguard fundamental rights in the AFSJ. The CEU should not consider the constitutional identity clause as a provision that weakens its position. In fact, some authors contend that a limited application of this identity review to integrate constitutional rights within the EU framework reinforces the legitimacy of the CJEU. ${ }^{60}$

In any case, in interpreting article 4(2) TEU, the CJEU should consider the legal traditions of all Member States, other identity reviews developed by other national Courts, and how they conceive their constitutional identities. Otherwise, the CJEU would be merely replicating German standards at EU level to ensure the full participation of this Member State rather than protecting defence rights. This is a critique that has been made of the Solange case-

\footnotetext{
${ }^{60}$ Hong (n Error! Bookmark not defined.), 563. In this article Hong affirms that: 'if [identity review for violations of human dignity] exercised responsibly, it will in all likelihood not weaken, but rather strengthen the legitimacy of the European Court of Justice. The dialogue taking place within the European and global community of courts will become increasingly indispensable.'
} 
law, ${ }^{61}$ and that the European Court could easily avoid by protecting the constitutional identity of its 28 Member States.

\section{The Taricco Saga as a New Beginning}

\subsection{Taricco I: Another Attempt to Foster Efficiency and Homogeneity?}

The so-called Taricco judgments (Case C-105/14 ${ }^{62}$ and Case C-42/17 ${ }^{63}$ ) raised great expectations among academics for several reasons. Different aspects, such as the importance of the protection of the principle of legality in relation with the retroactive derogation of time limitations ${ }^{64}$, the criminalisation of VAT fraud as a general objective of the EU ${ }^{65}$, or the principle of supremacy of national constitutions in relation with the primacy of EU law ${ }^{66}$ have been analysed. Another interesting aspect of these cases is the way in which the CJEU accommodated a certain degree of differentiation in the field of criminal law in order to protect fundamental rights and legal principles at national level. In other words, the CJEU's position in relation with the Taricco saga shows a pragmatic approach towards the primacy of EU law that also acknowledges a certain degree of differentiation at national level without referring to article $4(2)$ TEU.

The Taricco saga begins with the CJEU's judgment in Taricco I after the Court of Appeal of Cuneo launched a request for a preliminary ruling in the issue of time limitations in tax fraud. More specifically, the Court enquired about the compatibility of articles 101, 107, and 119 TFEU, article 158 of Directive 2006/112 of 28 November 2006 on the Common System of Value Added Tax with the regulation of time limitation in Italy, and the obligation to prosecute tax evasion in its question to the CJEU. ${ }^{67}$ The main issue at stake was deciding whether the

\footnotetext{
${ }^{61}$ Bill Davies ( $\left.\mathrm{n} 44\right)$.

62 Case C-105/14 Ivo Taricco and Others [2015] EU:C:2015:555 (Taricco I).

${ }^{63}$ Case C-42/17 M.A.S.and M.B [2017] EU:C:2017:936 (Taricco II).

${ }^{64}$ Michele Caianiello, 'Processo penale e prescrizione nel quadro della giurisprudenza europea. Dialogo tra sistemi o conflitto identitario?' (2017) 3 Revista Brasileira de Direito Processual Penal 967.

${ }^{65}$ Francesco Grisostolo and Luisa Scarcella, 'Trouble Always Comes in Threes: The Taricco Case Saga and the Italian Limitation Period in VAT Fraud' (2017) 45 Intertax, 701.

${ }^{66}$ Daniele Gallo, 'Controlimiti, identità nazionale e i rapporti di forza tra primato ed effetto diretto nella saga Taricco' (2017) 2 I/ Diritto dell'Unione Europea 277.

${ }^{67}$ Case Case C-105/14, Ivo Taricco and Others [2015] EU:C:2015:555, Request for a preliminary ruling from the Tribunale di Cuneo (Italy) lodged on 5 March 2014.
} 
short time limitations under Italian law and the limited possibilities of extension, even considering the interruption of these periods, constituted an instance of unfair competition that favoured companies established in Italy. The referring Court also enquired whether these laws favoured certain undertakings, and created a VAT unlawful exemption that is not included in Article 158(2) of Directive 2006/112. ${ }^{68}$ In this case that concerned tax fraud charges, the Court of Appeal of Cuneo claimed that the time limitation regime in Italy operates as a guarantee of impunity for tax evaders as, 'de facto impunity is a normal, rather than exceptional, occurrence'. ${ }^{69}$

In turn, the CJEU decided to change the parameters of its decision, and based its ruling on the interpretation of article 325 TFEU. This provision governs the obligation of Member States to counter fraud and any other illegal activities affecting the financial interests of the Union. In its ruling, the CJEU considered that the regulation of time limitations under Italian law contravened the obligation of prosecuting crimes against the financial interests of the EU as it made the imposition of effective and dissuasive penalties almost impossible, and ordered national courts to disapply them. ${ }^{70}$

This ruling is problematic for two reasons. First of all, it is an example of retroactive modification of criminal laws as it orders the disapplication of time limitations that were in force when the Italian Courts adjudicated the cases involving Ivo Taricco and other defendants. This disapplication would affect any tax offence that was about to prescribe, according to the Italian law in force when the tax offence was committed. This retroactive disapplication of time limitations was criticised, and considered a violation of the principle of legality as regulated by Italian law as well as an instance of judicial creation of criminal offences. $^{71}$

Secondly, the CJEU failed to take into account the peculiarities of time limitations within the Italian legal system, and examined the nature of these rules according to article 49 of the

\footnotetext{
68 Taricco I (n 62) para 25.

69 Taricco I (n 62), para 24.

${ }^{70}$ Ibid, para 58.

${ }^{71}$ See Alberto Camon, 'La torsione di un sistema. Riflessioni intorno alla Sentenza Taricco' (2014) Tribuna Focus 1; Vittorio Manes, 'La "Svolta" Taricco E La Potenziale "Sovversione Di Sistema": Le Ragioni Dei Controlimit' Diritto Penale Contemporaneo 1.. Both authors criticised this judgment as incompatible with the principle of legality, the requirement of precision in criminal law, the principle of certainty, the equal treatment of citizens in front of the law, the separation of powers, and the principle of nulla poena sine legge.
} 
Charter and article 7 ECHR, which enshrines the principle of legality within EU and ECHR law respectively. ${ }^{72}$ If this regulations are analysed, it seems clear that the principle of legality cannot be extended to rules of procedural nature as it is limited to substantive norms. ${ }^{73}$ If time limitations are not considered substantive in nature, their retroactive disapplication does not contravene the principle of legality. ${ }^{74}$ In doing so, the CJEU overlooked the nature and importance of time limitations under Italian law. Instead, the Court adopted the ECHR view as its own, and "forgot" to investigate the nature of time limitations according to Italian law.

Understanding the nature of time limitations is relevant in order to understand the consequences of disapplying them. If Italy is taken individually, it seems clear that time limitation rules are considered substantive in nature. ${ }^{75}$ Despite the Italian case being a rarity in the EU-wide context, there are other Member States, such as Spain, that also consider time limitation rules as substantive, and apply to them the same safeguards and principles as to any other area of substantive criminal law. ${ }^{76}$ Not examining the nature and role of time limitations in national law was one of the flaws of Taricco / that created another source of confrontation in an already complex issue.

In this case, the Court took a pragmatic approach that tried to eliminate the obstacles to effective prosecution of crimes against the financial interests of the EU. In fact, it could be argued that the fight against impunity in the cases of tax fraud and the fight against financial crimes made this approach all the more pertinent. Some authors went as far as considering this case as a conflict between constitutional rights: the social rights guaranteed under articles 2 and 3 of the Italian Constitution on the one hand, and the principle of legality in article 25(2)

\footnotetext{
72 Taricco I (n 62), paras 54-57.

${ }^{73}$ On the interpretation of article 7 ECHR as procedural rather than substantive: Coëme and Others v. Belgium, nos. 32492/96, 32547/96, 32548/96, 33209/96 and 33210/96, § 149, ECHR 2000-VI; Scoppola v. Italy (no. 2) [GC], no. 10249/03, § 110 and the case-law cited, 17 September 2009, and OAO Neftyanaya Kompaniya Yukos v. Russia, no. 14902/04, §§ 563, 564 and 570 and the case-law cited, 20 September 2011).

74 Ibid, paras 54-55: 'it would in no way lead to a conviction of the accused for an act or omission which did not constitute a criminal offence under national law at the time when it was committed, nor to the application of a penalty which, at that time, was not laid down by national law'.

${ }^{75}$ See Simone Risoli, 'Oltre il confine stabilito. Teoria e funzionamento dei "controlimiti"' (2017) 31 Stato, Chiesa e Pluralismo Confessionale 1; Massimo Nobili, Luigi Stortoni, Massimo Donini, Maria Virgilio, Marco Zanotti and Nicola Mazzacuva, 'Prescrizione e irretroattività fra diritto e procedura penale' (1998) 121 /l Foro Italiano 317.

${ }^{76}$ Spain considers time limitations as part of substantive criminal law and includes them in the Penal Code and not in the Statute of Criminal Procedure. For more information on the nature of time limitations in Spain: María Isabel González Tapia, La prescripción en el derecho penal (Dykinson 2003), 20.
} 
of the Constitution on the other. ${ }^{77}$ Even if this view could be sustained under Italian Constitutional Law, it is worth reminding that the CJEU did not consider this conflict. Indeed, the main characteristic of this ruling is that the Court disregarded national constitutional law (including a possible conflict of fundamental rights domestically), and prioritised the efficiency of EU law over the rights of the accused.

Nevertheless, Italian Courts picked up some of the problems concerning legal certainty, the precision of criminal conducts and punishments, and the judicial creation of criminal law. More precisely, the Court of Appeal of Milan and the Third Section of the Court of Cassation referred questions of unconstitutionality to the Corte Cost in relation with the application of Taricco $1 .{ }^{78}$ When addressing these questions, it acknowledged that time limitation rules were substantive in nature, and were covered by the principle of legality of article 25(2) of the Italian Constitution. ${ }^{79}$ Other incompatibilities concerned the lack of legal certainty, foreseeability, and precision in the application of criminal law following Taricco ${ }^{80}$, as well as the judicial creation of criminal law. ${ }^{81}$ The Corte Cost analysed all these incompatibilities with Italian constitutional law, expressed its concerns about it, and decided to launch another request for a preliminary ruling to the CJEU using the urgent procedure. ${ }^{82}$

\subsection{The Controlimiti Doctrine as a Viable Alternative}

The Corte Cost's request for a preliminary ruling could be considered a request to reconsider Taricco $I$ in light of Italian constitutional law. What this analysis fails to acknowledge is that there was an alternative that would have solved the incompatibility with EU law altogether,

\footnotetext{
77 Giuliana Ziccardi Capaldo, The Global Fight Against Impunity And The European Court Of Justice: A New Approach To Tax Fraud As A Crime Against Human Rights (European Law Blog 8 December 2017) http://europeanlawblog.eu/2017/12/08/the-global-fight-against-impunity-and-the-european-court-of-justicea-new-approach-to-tax-fraud-as-a-crime-against-human-rights/ Accessed on 8 May 2018.

${ }^{78}$ See Court of Appeal of Milan, Judgment 6421/15 of 18 September 2015 and Court of Cassation, Judgment 28364/16 of 30 March 2016 (Order of the ICC).

79 Italian Constitutional Court, Order No. 24 of 23 November 2016. Available online at http://people.unica.it/danieleamoroso/files/2012/04/pronuncia_24_2017.pdf, para 4.

80 Order of the Corte Cost, para 5. The Court noted that Taricco / requires Courts to disapply statutes of limitations, 'in situations in which this would have resulted in an exemption from punishment in a considerable number of cases involving serious fraud affecting the financial interest of the Union'. This solution is be contrary to the principle of foreseeability of criminal laws as an element of the principle of legality in Italian constitutional law.

$81 \mathrm{lbid}$, para 8.

82 Case C-47/2017 M.A.S. and M.B. [2017] ECR 168, Order of the Italian Constitutional Court requesting a preliminary ruling issued on 28 February 2017.
} 
but would have also opened an unprecedented conflict with the CJEU. This alternative can be found in the so-called controlimiti doctrine developed by the Corte Cost in order to expel rules of foreign origin (understood as EU and international) that threaten the core principles of the Italian Constitution. ${ }^{83}$

Although this doctrine was mainly born to expel rules of international origin, a judgment of 1973 extended it to EC legislation. ${ }^{84}$ This judgment determined that EC legislation will be declared void if it violates the core principles and rights of the Italian constitutional order. ${ }^{85}$ This doctrine can be reconciled with article 4(2) TEU as it allows a certain degree of differentiation in cases in which the constitutional identity of a Member State is at stake. Although this controlimiti doctrine does not refer specifically to the constitutional identity of Italy, it refers to the inalienable constitutional principles and rights of the Italian constitutional order. The controlimiti doctrine could be reconciled with article 4(2) TEU, and used as a narrow exception to protect higher fundamental rights standards upheld by the Italian legal system. More precisely, this exception could have been used by Italy to protect the rights of the accused against the retroactive modification of criminal laws.

The controlimiti doctrine operates similarly to the BVerfGE's identity review insofar as it accepts EU legislation a priori, and incorporates a general presumption of compatibility in favour of laws of European origin. But the Court also introduces an absolute limit to this general presumption in the protection of fundamental rights and principles inherent to the Italian constitutional identity. Some authors noted that the controlimiti doctrine equipped the Italian constitutional judges with the tools needed to expel the Taricco case-law from the Italian legal system. ${ }^{86}$

On the other hand, this solution would have meant ignoring the binding force of preliminary judgments, and their consideration as res judicata. At the same time, the unilateral nature of a domestic ruling issued by the Corte Cost would have precluded any dialogue with the CJEU on the possibility of protecting core principles and rights of Italian criminal law, even when

\footnotetext{
${ }^{83}$ On the origin, evolution and application of the controlimiti exception in Italy: Risoli (n 75).

84 Italian Constitutional Court, Ruling No. 183 of 18 December 1973. Available online at http://www.giurcost.org/decisioni/1973/0183s-73.html

85 Ibid, para. 9.

${ }^{86}$ On the application of the controlimiti case-law to Taricco I: Roberto Mastroianni, 'Supremazia Del Diritto Dell’Unione e "Controlimiti” Costituzionali: Alcune Riflessioni A Margine Del Caso Taricco “ (2016) Diritto Penale Contemporaneo 1; Manes (n 71).
} 
doing so means limiting the efficiency and coherence of EU law. Arguably, the decision taken by the Corte Cost is the most consistent with the duty of loyal cooperation, and it is probably the best alternative to foster a judicial dialogue about the interpretation and application of article 4(2) TEU into the criminal law sphere.

\subsection{Taricco II: The CJEU listening}

The Order of the Corte Cost that launched the request for a preliminary ruling to the CJEU clearly challenged the incompatibilities of Taricco I, and opened the possibility of a dialogue with the CJEU regarding the protection of national constitutional rights and principles in the AFSJ. At the same time, some argue that the wording of the Order could be perceived as a threat of disapplication of EU law if the CJEU did not correct its previous case-law. ${ }^{87}$ Although the ICC did not make this threat explicit, it is true that the existence of the controlimiti doctrine and the incompatibilities that the Corte Cost explained in the Order made the consequences of a ruling in line with Taricco / clear.

The CJEU delivered its preliminary ruling on 5 December 2017, in what came to be known as Taricco II. The Court corrected its previous case-law, but did not show any sign of selfcriticism. Instead, it blamed the referring Court in Taricco I (the Court of Appeal of Cuneo) for not explaining the implications of disapplying the statutes of limitations under Italian constitutional law. ${ }^{88}$ Although the CJEU could have used the Service of Research and Documentation to enquire about these issues, this is a valid criticism as it is not the CJEU's competence to interpret national legislation.

Additionally, the CJEU corrected its previous stance with regard to article 325 TFEU and the disapplication of time limitations in Italy. It maintained that the disapplication of these statutes of limitations was crucial to comply with article 325 TFEU, but noted that it was a task to be entrusted to the Italian Parliament. ${ }^{89}$ This means that the CJEU still deemed necessary to modify articles 160 and 161 of the Penal Code in order to bring them in line with

87 Dana Burchardt, Belittling the Primacy of EU Law in Taricco I/ (Verfassungsblog 7 December 2017) https://verfassungsblog.de/belittling-the-primacy-of-eu-law-in-taricco-ii/. Accessed on 12 February 2018. Burchardt argues that the preliminary reference was a threat to apply the controlimiti jurisprudence as well as the 'constitutional identity narrative' that the CJEU averted.

${ }^{88}$ Taricco II (n 63), para 28.

${ }^{89}$ Ibid, para 41. 
EU law, but it also understood that such modification could only be entrusted to the legislative to avoid a violation of Italian constitutional law.

The other interesting aspect of this ruling is that the CJEU corrected its previous stance on articles 7 ECHR and 49 of the Charter, and ruled that the decision of the Court in Taricco I implied, 'imposing conditions of criminal liability stricter than those in force at the time the infringement was committed'.$^{90}$ According to the CJEU, such decision would violate the requirements of certainty, precision, and foreseeability that are inherent to the principle of legality. ${ }^{91}$ In this sense, the CJEU did not only recognised that Italian law did not permit the retroactive disapplication of time limitations, but also acknowledged that its own interpretation of Charter and ECHR rules was irreconcilable with the principles of precision, certainty, and foreseeability that are inherent to criminal law.

Having analysed both rulings, it can be argued that Taricco I was a continuation of Melloni, whereas Taricco // accepted a certain degree of legal diversity in order to protect fundamental rights. Although the CJEU did not explicitly refer to article 4(2) TEU or to respect towards Italy's constitutional identity, Taricco /I indirectly shed light on both issues. The Court departed from Taricco I that replicated the priorities of Melloni, namely the protection of efficiency and the absolute supremacy of EU law at all costs, in order to accept a certain degree of differentiation that can be used preserve core constitutional principles that are part of the Italian constitutional identity. This mechanism can be extrapolated to judicial cooperation in criminal matters applying article 4(2) TEU, which could be used to safeguard defence rights beyond the minimum standard imposed by EU and ECHR law. In other words, preserving a certain degree of differentiation within the AFSJ may be the best alternative to avoid the race to the bottom in fundamental rights that has been criticised in Melloni and Taricco 1.92

In other words, Taricco /l can be a model of how the CJEU can use article 4(2) TEU and national standards to supplement the minimum fundamental rights provided by EU and ECHR. At the same time, this decision means limiting the so-called absolute primacy of EU law as applied

\footnotetext{
90 Ibid, para 62.

91 Ibid, paras 60-62.

92 See: Risoli (n 83); Camon (n 71); Aida Torres Pérez (n 35).
} 
to Melloni, and replacing it with a 'conditional primacy of EU law'. ${ }^{93}$ Moreover, the Taricco saga proves the importance of judicial dialogue between courts to ensure that fundamental rights are adequately protected. The fact that the Corte Cost did not unilaterally apply the controlimiti doctrine, and requested a preliminary ruling from the CJEU opened the door for a judicial dialogue that serves to improve the protection of fundamental rights in the field of European criminal law. The Corte Cost did not shy away from the possible conflict with the CJEU, and clearly explained the incompatibilities of Taricco / with Italian constitutional law and the consequences of having to implement such ruling domestically. By doing so, the Italian Court acted as a system of check and balances to the CJEU, ensuring that its decision would be in line with Italian constitutional law and with EU law.

Nevertheless, it has also been argued that Taricco I/ is more the result of an attempt to avoid an unilateral application of the controlimiti doctrine than a first step towards reconsidering the protection of fundamental rights in EU criminal law. ${ }^{94}$ The issue that this author raises it that the argumentation of the Court in Taricco // could be used by national courts to invoke constitutional rights and unilaterally disapply EU law. It is true that in a climate where an increasing number of national courts are developing ultras vires and identity reviews, the vague argumentation of the Court in this case could be used to unilaterally question the primacy of EU law. However, this also demonstrates the potential of article 4(2) TEU as a mechanism that limits the possibilities of disapplication to constitutional rights that are at the core of a Member State's national identity. It also shows that the preliminary ruling mechanism can be used to identify these fundamental rights, while judicial dialogue is a valid mechanism to establish the national standards worthy of protection under article 4(2) TEU.

In any case, it is too early to know if the arguments in Taricco // will be extrapolated to other areas, such as judicial cooperation in criminal matters, where fundamental rights have been more exhaustively harmonised. Nonetheless, it is relevant insofar as it shifts the parameters of the conversation from the issue of the absolute primacy of EU law in the AFSJ with Melloni to a more open approach towards national diversity in Taricco II.

\footnotetext{
${ }^{93}$ Michał Krajewski, 'Conditional' Primacy of EU Law and Its Deliberative Value: An Imperfect Illustration from Taricco I/ (Europeanlaw Blog 18 December 2018). Accessed on 22 February 2018.

${ }^{94}$ Dana Burchardt (n 87).
} 


\section{Conclusions}

The difference in fundamental rights standards within the EU has been a source of conflict since the early years of the AFSJ. The existence of an almost automatic mutual recognition that facilitates cooperation among Member States to fulfil security goals in areas, such as counter terrorism or transnational crime, relegated the rights of the accused to a secondary position. The post-Lisbon situation, however, brought the issue of fundamental rights to the forefront. As a consequence, the CJEU extended its full jurisdiction to the AFSJ, and minimum standards were adopted to reinforce the protection of defence rights across the EU. Additionally, the CJEU set a limit to judicial cooperation in cases of Member States that did not comply with EU and ECHR fundamental rights with the joint cases of Caldararu and Aranyosi.

All these decisions have improved the protection of the rights of the accused in the implementation of judicial cooperation measures. But this article has shown how this protection is currently limited to the safeguard of minimum standards, while higher standards upheld by Member States have to be disapplied in order to preserve the absolute primacy of EU law and the automaticity of mutual recognition. This issue was settled by the CJEU in Melloni, when the Court ruled that national fundamental rights standards could not be applied to areas under harmonisation. As this article has shown, this solution fails to provide an adequate framework for the protection of defence rights within the AFSJ.

The alternative proposed is applying the constitutional identity clause of article 4(2) TEU as a limited exception to preserve higher standards available at national level. If interpreted in a similar way to the BVerfGE's identity review explained in Section 3 , the constitutional identity exception constitutes a powerful tool to preserve fundamental rights that are at the core of Member States' constitutional identities. At the same time, this exception can be used to signal the areas in which additional safeguards are needed to facilitate the automaticity of mutual recognition, e.g. trials in absentia.

In turn, the constitutional identity exception, as explained in Section 2, has the advantage of being more limited in scope than the interpretation of article 53 of the Charter as a minimum floor of protection. This interpretation of article 53 would enable Member States to impose 
additional safeguards in relation with every fundamental right, which would challenge the efficiency and operability of mutual recognition in criminal matters. Instead, article 4(2) TEU, if interpreted similarly to the Solange case-law, acts as an exception with a very limited scope that would only operate in cases in which the core content of a constitutional right is at risk. The cases in which a national court has triggered an identity review of some sort or raised the issue of constitutional rights violations are very limited, as it has been seen in Sections 3 and 4. In any case, these have all been instances in which applying EU law might have amounted to an unacceptable violation of fundamental rights.

Overall, this article has looked into the potential of re-opening the judicial dialogue between the CJEU and national constitutional courts after the standstill that followed Melloni to consider the potential of applying article 4(2) TEU to limit the automaticity of mutual recognition. In fact, the Taricco saga has demonstrated that the CJEU is willing to accept a certain degree of differentiation in order to preserve fundamental rights that are inherent to the constitutional identity of Member States. Despite Taricco concerning a field where harmonisation has not developed as much as in judicial cooperation in criminal matters, the tendency towards dialogue and cooperation with regard to fundamental rights standards should be extrapolated to this area.

This new phase should be characterised by an acknowledgment of the applicability of article 4(2) TEU into the field of judicial cooperation in criminal matters. Despite the improvement represented by Taricco, the CJEU did not refer to constitutional identity or article 4(2) TEU and, as previously explained, the argumentation could be used to limit integration in any area in which a national court thinks that constitutional rights are compromised. Instead, a rigorous application of article 4(2) TEU in a context of judicial dialogue between national courts and the CJEU could improve fundamental rights protections and limit the selfinterested use of constitutional diversity. The role of national courts through the preliminary reference is necessary to open this dialogue, which also requires that they refrain from a unilateral interpretation of EU law, and follow the example of the Italian Corte Cos in Taricco II. Then, it will also be necessary that the CJEU delimits the application of the constitutional identity exception through a ruling that does not take its classical "individualised" approach, and can be extrapolated to the whole AFSJ. 


\section{References}

Alegre S and Leaf M, 'Mutual Recognition in European Judicial Cooperation: A Step Too Far Too Soon? Case Study-the European Arrest Warrant' (2004) 10 European Law Journal 200.

Alter K, Establishing the Supremacy of European Law: The Making of an International Rule of Law in Europe (Oxford University Press, 2001) 94.

Anagnostaras G, 'Solange III? Fundamental rights protection under the national identity review' (2017) 42 European Law Review 234.

Besselink L F, A Composite European Constitution (Europa Law Publishing 2007).

Besselink LF, 'National and constitutional identity before and after Lisbon', (2010) 6 Utrecht Law Review 3

Blanke H-J and Mangiameli S (eds.), The Treaty on European Union (TEU): A Commentary (Springer 2013).

Brouwer E, 'Mutual Trust and the Dublin Regulation: Protection of Fundamental Rights in the EU and the Burden of Proof' 9 Utrecht Law Review 135.

Burchardt D, Belittling the Primacy of EU Law in Taricco II (Verfassungsblog 7 December 2017) https://verfassungsblog.de/belittling-the-primacy-of-eu-law-in-taricco-ii/

Caianiello M, 'Processo penale e prescrizione nel quadro della giurisprudenza europea. Dialogo tra sistemi o conflitto identitario?' (2017) 3 Revista Brasileira de Direito Processual Penal 967.

Camon A, 'La torsione di un sistema. Riflessioni intorno alla Sentenza Taricco' (2014) Tribuna Focus 1.

Committee for the Prevention of Torture of the Council of Europe, Rapport au Gouvernement de la Roumanie relatif à la visite effectuée en Roumanie par le Comité européen pour la prévention de la torture et des peines ou traitements inhumains ou dégradants du 5 au 17 juin 2014 (2015).

Davies B, 'Resistance to European Law and Constitutional Identity in Germany: Herbert Kraus and Solange in its Intellectual Context' (2015) 21 European Law Review 434.

Gallo D, 'Controlimiti, identità nazionale e i rapporti di forza tra primato ed effetto diretto nella saga Taricco' (2017) 2 II Diritto dell'Unione Europea 277.

González Tapia M I, La prescripción en el derecho penal (Dykinson 2003).

Grisostolo F and Scarcella L, 'Trouble Always Comes in Threes: The Taricco Case Saga and the Italian Limitation Period in VAT Fraud' (2017) 45 Intertax 701. 
Guild E, Constitutional challenges to the European Arrest Warrant (Wolf Legal Publishers 2007).

Hong M, 'Human Dignity, Identity Review of the European Arrest Warrant and the Court of Justice as a Listener in the Dialogue of Courts: Solange-III and Aranyosi' (2016) 12 European Constitutional Law Review 549.

Janssens C, 'The Principle of Mutual Recognition as Legislative Impetus for Efficient Judicial Cooperation in Criminal Matters', in The Principle of Mutual Recognition in EU law (Oxford Publishers 2013).

Justice, European Arrest Warrants: Ensuring an Effective Defence (2012 Justice Report).

Krajewski M, 'Conditional' Primacy of EU Law and Its Deliberative Value: An Imperfect Illustration from Taricco II (European Law Blog 18 December 2018). Accessed on 22 February 2018.

Manes V, 'La "Svolta" Taricco E La Potenziale "Sovversione Di Sistema": Le Ragioni Dei Controlimit' Diritto Penale Contemporaneo 1.

Mastroianni R, 'Supremazia Del Diritto Dell'Unione e "Controlimiti" Costituzionali: Alcune Riflessioni A Margine Del Caso Taricco ‘ (2016) Diritto Penale Contemporaneo 1.

Mitsilegas V, EU Criminal Law after Lisbon: Rights, Trust and the Transformation of Justice in Europe (Bloomsbury 2016).

Mitsilegas V, 'The Principle of Mutual Recognition as Legislative Impetus for Efficient Judicial Cooperation in Criminal Matters' (2015) 6 New Journal of European Criminal Law 457.

Nobili M, Stortoni S, Donini M, Virgilio M, Zanotti M and Mazzacuva N, 'Prescrizione e irretroattività fra diritto e procedura penale' (1998) 121 // Foro Italiano 317.

Risoli S, 'Oltre il confine stabilito. Teoria e funzionamento dei "controlimiti"' (2017) 31 Stato, Chiesa e Pluralismo Confessionale 1.

Gáspár-Szilágyi S, 'Joined Cases Aranyosi and Caldararu: Converging Human Rights Standards, Mutual Trust and a New Ground for Postponing a European Arrest Warrant' (2016) 24 European Journal of Crime, Criminal Law and Criminal Justice 197.

Torres Pérez A, 'Melloni in Three Acts: From Dialogue to Monologue' (2014) 10 European Constituional Law Review 308.

Van de Heyning C, 'No Place Like Home-Discretionary Space for the Domestic Protection of Fundamental Rights', in Piet Van Nuffel, Catherine van de Heyning, Patricia Popelier (eds), Human Rights Protection in the European Legal Order: The Interaction between the European and the National Courts (Intersentia 2011) 
Weyembergh A, 'Critical Assessment of the Existing European Arrest Warrant Framework Decision' in European Added Value Assessment The EU Arrest Warrant (2014) European Parliamentary Research Service EAVA 6/2013. 